\title{
Correction: Prognostic factors in patients with vulvar cancer: the VULCAN study
}

Zapardiel I, lacoponi S, Coronado PJ, et al. Prognostic factors in patients with vulvar cancer: the VULCAN study. Int J Gynecol Cancer 2020;30:1285-91.

This article has been corrected since it was first published. There were typographical errors in Tables 2 and 3 ; the third and fourth columns in Tables 2 and 3 were unintentionally switched, so the hazard ratios and confidence intervals from Table 2 corresponded to Table 3; and those from Table 3 corresponded to Table 2. This has now been corrected.

(C) Author(s) (or their employer(s)) 2020. No commercial re-use. See rights and permissions. Published by BMJ. Int J Gynecol Cancer 2020;30:2023. doi:10.1136/ijgc-2019-000526corr1

A) Check for updates 